\title{
Pengaruh Program E-SAMSAT, SAMSAT Keliling, dan Kepuasan Wajib Pajak pada Kepatuhan Wajib Pajak Kendaraan Bermotor
}

\author{
Ni Komang Megi Megayani ${ }^{1}$ \\ Fakultas Ekonomi dan Bisnis \\ Universitas Udayana, Indonesia
}

\author{
Naniek Noviari ${ }^{2}$ \\ Fakultas Ekonomi dan Bisnis \\ Universitas Udayana, Indonesia
}

Surel: megimegayani99@gmail.com

ABSTRAK

Penelitian ini bertujuan untuk mengetahui pengaruh program eSAMSAT, SAMSAT keliling, dan kepuasan wajib pajak pada kepatuhan wajib pajak kendaraan bermotor. Teori yang digunakan dalam penelitian ini adalah Theory of Planned Behavior dan teori Technology Acceptance Model. Penelitian ini dilakukan di Kantor Bersama SAMSAT Karangasem dengan jumlah populasi sebanyak 205.849 wajib pajak. Besarnya sampel dihitung menggunakan rumus slovin sehingga sampel berjumlah 100 wajib pajak. Metode penentuan sampel menggunakan accidental sampling. Pengumpulan data dilakukan melalui penyebaran kuesioner dan teknik analisis data yang digunakan adalah analisis regresi linear berganda. Berdasarkan hasil analisis disimpulkan bahwa, program e-SAMSAT, SAMSAT keliling, dan kepuasan wajib pajak berpengaruh positif pada kepatuhan wajib pajak kendaraan bermotor di Kantor Bersama SAMSAT Karangasem.

Kata Kunci: Program E-SAMSAT; SAMSAT Keliling; Kepuasan Wajib Pajak; Kepatuhan Wajib Pajak.

\section{The Influence Of The E-SAMSAT Program, SAMSAT Roving, and Tax Payer's Satisfaction to Motor Vehicle Taxpayer Compliance}

\begin{abstract}
The research aims determine the effect of $e-S A M S A T, S A M S A T$ roving, and taxpayer satisfaction on motor vehicle taxpayer compliance. The theories used in this study are Theory of Planned Behavior and the Technology Acceptance Model theory. This research was conducted at the Joint Office of SAMSAT Karangasem with a total population of 205,849 taxpayers and sample size was calculated using the Slovin formula so that the sample size was 100 taxpayers. The method of determining the sample using accidental sampling is taking samples by chance. Data collection was carried out by distributing questionnaire, and the analysis technique used was multiple linear regression analysis. Based on results of the analysis, it is concluded that the e-SAMSAT program, SAMSAT roving, and taxpayer satisfaction have a positive effect on motor vehicle taxpayers compliance at the Joint Office of SAMSAT Karangasem.

Keywords: E-SAMSAT Program; SAMSAT Roving; Tax Payer's Satisfaction; Taxpayer Compliance.
\end{abstract}

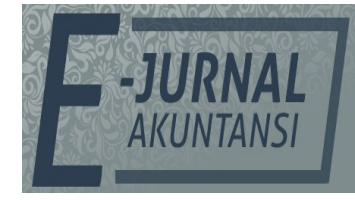

e-ISSN 2302-8556

Vol. 31 No. 8

Denpasar, Agustus 2021 Hal. 1936-1946

DOI:

10.24843/EJA.2021.v31.i08.p05

PENGUTIPAN:

Megayani, N.K.M., \&

Noviari, N. (2021). Pengaruh

Program E-SAMSAT,

SAMSAT Keliling, dan

Kepuasan Wajib Pajak pada

Kepatuhan Wajib Pajak

Kendaraan Bermotor. E-Jurnal Akuntansi, 31(8), 1936-1946

RIWAYAT ARTIKEL: Artikel Masuk: 2 Desember 2020 Artikel Diterima: 25 Februari 2021

Artikel dapat diakses : https://ojs.unud.ac.id/index.php/Akuntansi/index 


\section{PENDAHULUAN}

Otonomi daerah memberikan kewenangan yang begitu besar bagi daerah untuk mengatur dan mengurus rumah tangganya sendiri (Ardiyanti \& Supadmi, 2020). Pengembangan otonomi pada daerah kabupaten dan kota diselenggarakan dengan memerhatikan prinsip demokrasi, peran serta masyarakat, dan keadilan serta potensi untuk mengurangi ketergantungan fiskal terhadap pemerintah dan meningkatkan kemandirian daerah (Mahaputri \& Noviari, 2016). Pemerintah daerah diharapkan dapat memaksimalkan pemanfaatan sumber penerimaan daerah yang berpotensial, termasuk pajak daerah dan retribusi daerah sebagai unsur utama pendapatan asli daerah.

Pajak Kendaraan Bermotor (PKB) merupakan pajak daerah yang memberikan kontribusi yang cukup besar untuk meningkatkan pendapatan asli daerah lain (Dwipayana et al., 2017). PKB digunakan untuk membiayai pembangunan daerah provinsi. Instansi yang menangani pembayaran PKB adalah Dinas Pendapatan Daerah (Dispenda) melalui Kantor Bersama Sistem Administrasi Manunggal di bawah Satu Atap (SAMSAT) yang merupakan kerja sama tiga instansi terkait, yaitu Dispenda Provinsi Bali, Kepolisian RI, dan Asuransi Jasa Raharja (Hartana \& Merkusiwati, 2018).

Kantor Bersama SAMSAT Karangasem merupakan tempat pembayaran pajak kendaraan bermotor bagi wajib pajak di Kabupaten Karangasem. Selama 3 tahun terakhir yaitu tahun 2017-2019 jumlah kendaraan bermotor di Kabupaten Karangasem msengalami peningkatan. Hal tersebut dapat dilihat pada Tabel 1, berikut.

Tabel 1. Jumlah Kendaraan Bermotor yang Tercatat di Kabupaten Karangasem Tahun 2017-2019

\begin{tabular}{clccc}
\hline & & \multicolumn{3}{c}{ Tahun } \\
\cline { 3 - 5 } No. & Jenis Kendaraan & 2017 & 2018 & 2019 \\
& & 408 & 445 & 434 \\
$($ Unit $)$ & 408 & 961 \\
\hline 1 & Sedan & 818 & 916 & 11.736 \\
2 & Jeep & 9.792 & 10.824 & 232 \\
3 & Minibus & 209 & 237 & 6.368 \\
4 & Bus & 5.607 & 6.108 & 3.368 \\
5 & Pick Up & 2.940 & 3.264 & 182.750 \\
6 & Truck & 157.055 & 176.109 & \\
7 & Sepeda Motor & & & \\
& & 176.829 & 197.903 & 205.849 \\
\hline
\end{tabular}

Sumber: UPTD Pelayanan Pajak dan Retribusi Daerah Provinsi Bali di Kabupaten Karangasem, 2020

Tabel 1, menunjukkan bahwa jumlah kendaraan bermotor pada tahun 2017-2019 mengalami peningkatan. Semakin tinggi jumlah kendaraan bermotor yang beredar menyebabkan semakin meningkatnya jumlah wajib pajak dan penerimaan PKB di Kabupaten Karangasem. Namun, berdasarkan fenomena yang terjadi saat ini dan didukung data yang ada jumlah tunggakan PKB di Kabupaten Karangasem mengalami peningkatan. Hal tersebut membuat penelitian dengan topik kepatuhan wajib pajak di Kabupaten Karangasem menarik untuk diteliti. 
Tabel 2. Jumlah Target, Penerimaan, dan Tunggakan Pajak Kendaraan Bermotor pada Kantor Bersama SAMSAT Kabupaten Karangasem Tahun 20172019

\begin{tabular}{ccccc}
\hline Tahun & $\begin{array}{c}\text { Target } \\
(\mathrm{Rp})\end{array}$ & $\begin{array}{c}\text { Penerimaan } \\
(\mathrm{Rp})\end{array}$ & Persentase & $\begin{array}{c}\text { Tunggakan } \\
(\mathrm{Rp})\end{array}$ \\
\hline 2017 & 45.143 .070 .554 & 52.555 .045 .307 & $112,11 \%$ & 4.587 .937 .900 \\
2018 & 52.890 .320 .933 & 61.398 .402 .350 & $112,68 \%$ & 4.594 .236 .200 \\
2019 & 58.976 .336 .213 & 67.412 .378 .165 & $110,88 \%$ & 6.985 .387 .600 \\
\hline
\end{tabular}

Sumber: UPT D Pelayanan Pajak dan Retribusi Daerah Provinsi Bali di Kabupaten Karangasem, 2020

Tabel 2, menunjukkan bahwa jumlah tunggakan pajak kendaraan bermotor di Kabupaten Karangasem tahun 2017-2019 mengalami peningkatan yang signifikan. Hal tersebut menunjukkan masih rendahnya kepatuhan wajib pajak dalam melaksanakan kewajiban perpajakannya.

Kepatuhan pajak merupakan suatu keadaan dimana wajib pajak memenuhi semua kewajiban perpajakan dan melaksanakan hak perpajakannya (Winerungan, 2013). Menurut Awaluddin \& Tamburaka (2017) kepatuhan wajib pajak merupakan kondisi dimana wajib pajak melaksanakan dan memenuhi kewajiban perpajakannya dengan baik dan benar sesuai dengan peraturan perpajakan.

Faktor yang memengaruhi penerimaan pajak suatu daerah diantaranya adalah tingkat kepatuhan wajib pajak di daerah tersebut (Ariyanto, 2020) dan (Chau \& Leung, 2009). Demi terciptanya target pajak yang diinginkan perlu ditingkatkan kepatuhan wajib pajak dalam melaksanakan kewajibannya (Doran, 2009). Meningkatnya kepatuhan wajib pajak akan mendukung upaya pemerintah untuk meningkatkan kesejahteraan masyarakat (Gerald, 2009). Davis et al., (2003) menyebutkan bahwa seseorang yang mengetahui wajib pajak yang tidak patuh, maka seseorang tersebut kemungkinan akan memiliki kecenderungan mengikuti ketidakpatuhan tersebut.

Menurut Torgler (2005) dan Razak (2013) pencapaian tingkat kepatuhan wajib pajak saat ini merupakan isu yang menjadi perhatian para pembuat kebijakan ekonomi baik di negara maju maupun negara berkembang. Pau \& Hammer (2013) menyatakan bahwa masalah kepatuhan wajib pajak adalah masalah yang penting di seluruh dunia karena jika wajib pajak tidak patuh maka akan menimbulkan keinginan untuk melakukan tindakan penghindaran, pengelakan, dan pelalaian pajak.

Penerimaan pajak dapat dimaksimalkan dengan meningkatkan kepatuhan wajib pajak, karena pajak merupakan salah satu sumber pendapatan yang penting (Pertiwi, 2013). Salah satu upaya untuk meningkatkan kepatuhan wajib pajak yaitu dengan memanfaatkan teknologi yang ada. Saat ini pemerintah menerapkan program e-SAMSAT yang dapat memudahkan wajib pajak membayar pajak kendaraan bermotor dengan sistem online. Berdasarkan penelitian yang dilakukan Winasari (2020) sistem e-SAMSAT dapat memengaruhi kepatuhan wajib pajak kendaraan bermotor.

Selain program e-SAMSAT, SAMSAT keliling juga dapat meningkatkan kepatuhan wajib pajak. SAMSAT keliling merupakan layanan pengesahan Surat Tanda Nomor Kendaraan, pembayaran PKB, dan Santunan Wajib Dana Kecelakaan Lalu Lintas Jalan dengan menggunakan kendaraan bermotor yang beroperasi dari satu tempat ke tempat yang lain (Dwipayana et al., 2017). Layanan 
SAMSAT keliling diharapkan dapat mendekatkan pemerintah dengan wajib pajak kendaraan bermotor dan menumbuhkan kesadaran untuk lebih taat membayar pajak.

Hal ini didukung oleh penelitian Dwipayana et al (2017) yang menyatakan bahwa SAMSAT keliling berpengaruh positif terhadap kepatuhan wajib pajak kendaraan bermotor. Layanan SAMSAT keliling yang semakin baik akan meningkatkan niat wajib pajak untuk melaksanakan kewajiban perpajakannya sehingga kepatuhan wajib pajak akan meningkat. Selain itu, faktor lain untuk meningkatkan kepatuhan wajib pajak adalah kepuasan wajib pajak. Menurut Awaluddin et al (2017) kepuasan merupakan tingkat perasaan konsumen setelah membandingkan antara apa yang diterima dengan harapannya. Berdasarkan penelitian Suseno \& Sani (2018) menyatakan bahwa kepuasan wajib pajak berpengaruh positif dan signifikan pada kepatuhan wajib pajak.

Berdasarkan latar belakang masalah maka perumusan masalah penelitian ini, Apakah program e-SAMSAT berpengaruh pada kepatuhan wajib pajak kendaraan bermotor di Kantor Bersama SAMSAT Karangasem? Apakah SAMSAT keliling berpengaruh pada kepatuhan wajib pajak kendaraan bermotor di Kantor Bersama SAMSAT Karangasem? Apakah kepuasan wajib pajak berpengaruh pada kepatuhan wajib pajak kendaraan bermotor di Kantor Bersama SAMSAT Karangasem?

Theory of planned behavior memelajari perilaku manusia terkait minat seseorang, menyediakan suatu kerangka untuk mempelajari sikap individu terhadap perilaku serta dapat memprediksi berbagai jenis perilaku dengan akurasi tinggi melalui norma subjektif, kontrol perilaku, dan sikap (Ghouri et al., 2016). Theory of Planned Behavior relevan menjelaskan perilaku wajib pajak dalam memenuhi kewajibannya. Teori ini berkaitan dengan variabel SAMSAT Keliling yang dipengaruhi oleh persepsi kendali perilaku dari faktor eksternal, yang berasal dari lingkungan yang ada di sekeliling individu untuk meyakini tentang keberadaan hal-hal yang mendukung atau menghambat perilaku yang akan ditampilkan. SAMSAT keliling akan mempermudah wajib pajak dan dapat menghemat waktu dalam membayar kewajiban perpajakannya. Theory of Planned Behaviour berkaitan dengan variabel kepuasan wajib pajak dengan meningkatnya kepuasan wajib pajak atas pelayanan yang diberikan yang akan memotivasi wajib pajak untuk patuh (normative belief).

Technology Acceptance Model (TAM) merupakan salah satu model yang dibangun untuk menganalisis dan memahami faktor-faktor yang mempengaruhi diterimanya penggunaan teknologi komputer Teori Technology Acceptance Model (TAM) relevan untuk variabel ini karena dengan memanfaatkan teknologi yang ada penerapan e-SAMSAT diharapkan dapat memudahkan wajib pajak dalam membayar pajak kendaraan bermotor.

Sistem e-SAMSAT atau elektronik SAMSAT merupakan layanan pembayaran kendaraan bermotor yang dilakukan melalui e-banking atau ATM perbankan yang sudah ditentukan. E-SAMSAT ini dapat memudahkan para wajib pajak pada saat membayar pajak kendaraan bermotor. Wardani \& Juliansya (2018) melakukan penelitian bahwa program e-SAMSAT berpengaruh positif terhadap kepatuhan wajib pajak kendaraan bermotor karena dinilai efektif dan efisien dalam memberikan kemu dahan kepada wajib pajak kendaraan bermotor dalam melakukan pembayaran pajak. Hal ini juga didukung oleh penelitian Hertiarani (2016), yang menemukan bahwa pelayanan pajak kendaraan bermotor dapat 
berjalan dengan efektif dan efisien dilihat dari pemberian pelayanan yang cepat dan mudah dengan sistem online. Penelitian ini juga didukung oleh penelitian Dewi \& Laksmi (2019) yang menyatakan bahwa penerapan e-SAMSAT dapat meningkatkan kepatuhan wajib pajak kendaraan bermotor. Berdasarkan pembahasan teori dan hasil penelitian sebelumnya, maka hipotesis pertama dalam penelitian ini adalah sebagai berikut.

$\mathrm{H}_{1}$ : Program e-SAMSAT berpengaruh positif pada kepatuhan wajib pajak kendaraan bermotor di kantor bersama SAMSAT Karangasem.

SAMSAT Keliling merupakan layanan pengesahan Surat Tanda Nomor Kendaraan, pembayaran PKB, dan Sumbangan Wajib Dana Kecelakaan Lalu Lintas Jalan dengan menggunakan kendaraan bermotor yang beroperasi dari satu tempat ke tempat yang lainnya. Ardiani et al (2016) dalam penelitiannya mengungkapkan bahwa ada kepuasan yang dirasakan wajib pajak dengan adanya layanan inovasi SAMSAT keliling, karena dianggap lebih memudahkan wajib pajak. Penelitian Rohemah et al., (2016) menyatakan bahwa SAMSAT keliling berpengaruh terhadap kepatuhan wajib pajak, sedangkan fasilitas dan website tidak berpengaruh terhadap kepatuhan wajib pajak. Hal ini juga didukung oleh penelitian yang dilakukan oleh Mutia \& Hamta (2020) yang menyatakan bahwa SAMSAT keliling berpengaruh signifikan terhadap kepatuhan pajak kendaraan bermotor. Pernyataan ini juga sejalan dengan penelitian Ardiyanti \& Supadmi (2020) penerapan layanan SAMSAT keliling berpengaruh positif pada kepatuhan wajib pajak kendaraan bermotor. Berdasarkan pembahasan teori dan penelitian sebelumnya dapat dinyatakan bahwa semakin baik penerapan SAMSAT keliling, kepatuhan wajib pajak kendaraan bermotor juga akan meningkat, maka hipotesis kedua dalam penelitian ini adalah sebagai berikut.

$\mathrm{H}_{2}$ : SAMSAT keliling berpengaruh positif pada kepatuhan wajib pajak kendaraan bermotor di kantor bersama SAMSAT Karangasem.

Kepuasan wajib pajak adalah suatu keadaan dimana keinginan harapan dan kebutuhan wajib pajak dipenuhi (Dwipayana et al., 2017). Menurut Wardani \& Juliansya (2018) kepuasan wajib pajak adalah terpenuhinya tuntutan dan kebutuhan konsumen atas pelayanan sesuai harapannya, dengan indikator hasil kerja petugas sesuai harapan, fasilitas dan persyaratan sesuai dengan spesifikasi. Berdasarkan penelitian Dwipayana et al., (2017) yang menyatakan bahwa kepuasan wajib pajak berpengaruh positif kepada kepatuhan wajib pajak. Hal ini juga didukung oleh penelitian Awaluddin \& Tamburaka (2017) yang menyatakan bahwa kepuasan wajib pajak berpengaruh positif terhadap kepatuhan wajib pajak kendaraan bermotor. Berdasarkan penelitian sebelumnya, maka hipotesis ketiga pada penelitian ini adalah sebagai berikut.

$\mathrm{H}_{3}$ : Kepuasan wajib pajak berpengaruh positif pada kepatuhan wajib pajak kendaraan bermotor di kantor bersama SAMSAT Karangasem.

\section{METODE PENELITIAN}

Lokasi penelitian dilakukan di Kantor Bersama SAMSAT Karangasem yang beralamat di Jalan Achmad Yani, Subagan, Kecamatan Karangasem, Kabupaten Karangasem. Objek penelitian ini adalah kepatuhan wajib pajak dalam membayar pajak kendaraan bermotor di Kantor Bersama SAMSAT Karangasem 
yang dijabarkan oleh variabel program e-SAMSAT, SAMSAT keliling, dan kepuasan wajib pajak. Populasi dalam penelitian ini adalah seluruh wajib pajak kendaraan bermotor yang terdaftar di Kantor Bersama SAMSAT Karangasem yang berjumlah 205.849 wajib pajak.

Jumlah sampel yang digunakan pada penelitian ini dihitung menggunakan rumus Slovin sehingga sampel berjumlah 100 wajib pajak. Metode penentuan sampel pada penelitian ini menggunakan metode accidental sampling yaitu menentukan sampel berdasarkan kebetulan, yaitu siapa saja yang secara kebetulan bertemu dengan peneliti dan dipandang sesuai sebagai sumber data. Teknik pengumpulan data yang digunakan dalam penelitian ini adalah kuesioner. Jawaban responden diberi nilai/skor menggunakan skala likert modifikasi 1 sampai 4, yaitu 1) sangat tidak setuju diberi skor 1,2) tidak setuju diberi skor 2,3) setuju diberi skor 3, dan 4) sangat setuju diberi skor 4.

Kepatuhan wajib pajak adalah persepsi terhadap kondisi dimana wajib pajak memenuhi kewajiban perpajakannya dan melaksanakan hak perpajakan dengan baik dan benar sesuai dengan peraturan dan undang-undang pajak yang berlaku (Wardani \& Rumiyatun, 2017). Kepatuhan wajib pajak pada penelitian ini diukur dengan indikator yang mengadopsi dari penelitian Wardani \& Rumiyatun (2017) yaitu, memenuhi kewajiban pajak sesuai dengan ketentuan yang berlaku, membayar pajaknya tepat pada waktunya, wajib pajak memenuhi persyaratan dalam membayar pajaknya, dan wajib pajak mengetahui jatuh tempo pembayaran pajaknya.

Program e-SAMSAT merupakan pelayanan publik yang dibuat pemerintah daerah terhadap persepsi wajib pajak dalam melakukan pembayaran pajak kendaraan bermotor dengan mudah, nyaman, dan aman (Wardani \& Juliansya, 2018). Indikator yang digunakan untuk mengukur variabel program e-SAMSAT pada penelitian ini mengadopsi dari penelitian Wardani dan Juliansya (2018) yaitu, Cepat, Efektif, Efisien, Mudah, dan Aman.

SAMSAT keliling adalah layanan berupa pengesahan STNK, pembayaran PKB, dan SWDKLLJ dengan aktivitasnya menggunakan kendaraan bermotor yang beroperasi dari satu tempat ke tempat lainnya, yang memberikan kemudahan bagi wajib pajak dalam membayar pajak kendaraan bermotor sehingga wajib pajak lebih taat dalam mematuhi ketentuan perpajakan yang berlaku. Indikator yang digunakan untuk mengukur variabel SAMSAT keliling pada penelitian ini yaitu, Pendataan lebih terkontrol yaitu pendataan pada wajib pajak akan lebih mudah untuk kendaraan bermotor, Kemudahan membayar pajak adalah wajib pajak akan mudah dalam membayarkan pajaknya, Minat wajib pajak yaitu kemauan pada wajib pajak secara sukarela untuk membayar pajak, Menghemat waktu yaitu waktu yang digunakan wajib pajak lebih cepat dalam membayar pajak, Kualitas pelayanan yaitu seberapa besar layanan yang diberikan seseorang kepada wajib pajak saat membayar pajak, Letak wilayah yaitu suatu tempat yang digunakan untuk lokasi pembayaran pajak.

Kepuasan wajib pajak adalah persepsi wajib pajak terhadap kualitas pelayanan yang diberikan pemerintah kepada wajib pajak (Suseno \& Sani, 2018). Indikator yang digunakan untuk mengukur variabel kepuasan wajib pajak pada penelitian menggunakan salah satu dari dimensi SERVQUAL yaitu Tangible atau bukti fisik yaitu, kemampuan suatu perusahaan dalam menunjukkan eksistensnya 
pada pihak eksternal. Penampilan dan kemampuan yang diberikan oleh pemberi jasa, yang meliputi penampilan fasilitas fisik, peralatan, personil, dan materi komunikasi.

Data penelitian dianalisis dengan menggunakan analisis regresi linear berganda. Sebagai syarat regresi, dilakukan uji asumsi klasik berupa uji normalitas, uji multikoninearitas, uji heteroskedastisitas untuk melihat kesesuaian data penelitian. Dari hasil analisis regresi linear berganda dapat diketahui mengenai uji determinasi $\left(R^{2}\right)$, uji kelayakan model (Uji F), dan uji hipotesis (Uji t).

\section{HASIL DAN PEMBAHASAN}

Analisis data menggunakan model regresi linear berganda. Sebelum dilakukan uji analisis, data penelitian terlebih dahulu harus lolos uji asumsi klasik agar terbebas dari masalah normalitas, multikoleniearitas, dan heteroskedastisitas. Setelah dipastikan lolos dan memenuhi syarat regresi, maka dilakukan uji analisis regresi linear berganda dengan hasil berdasarkan Tabel 3, berikut.

\section{Tabel 3. Hasil Uji Regresi Linear Berganda}

\begin{tabular}{|c|c|c|c|c|c|c|}
\hline \multicolumn{2}{|c|}{ Model } & \multicolumn{2}{|c|}{$\begin{array}{l}\text { Unstandardized } \\
\text { Coefficients }\end{array}$} & \multirow{2}{*}{$\begin{array}{c}\begin{array}{c}\text { Standardized } \\
\text { Coefficients }\end{array} \\
\text { Beta }\end{array}$} & \multirow[t]{2}{*}{$\mathrm{t}$} & \multirow[t]{2}{*}{ Sig. } \\
\hline & & B & Std. Error & & & \\
\hline \multirow{4}{*}{1} & (Constant) & $-13,531$ & 2,071 & & $-6,534$ & 0,000 \\
\hline & Program E-SAMSAT & 0,071 & 0,036 & 0,150 & 2,004 & 0,048 \\
\hline & SAMSAT Keliling & 0,289 & 0,037 & 0,568 & 7,723 & 0,000 \\
\hline & Kepuasan Wajib Pajak & 0,169 & 0,034 & 0,376 & 5,017 & 0,000 \\
\hline
\end{tabular}

Sumber: Data Penelitian, 2020

Pada Tabel 3, dapat diketahui bahwa, persamaan regresi yang dihasilkan adalah sebagai berikut.

$$
Y=-13,531+0,071 X_{1}+0,289 X_{2}+0,169 X_{3}
$$

Nilai konstanta sebesar -13,531 menunjukkan variabel program e-SAMSAT $\left(X_{1}\right)$, SAMSAT keliling $\left(X_{2}\right)$, dan kepuasan wajib pajak $(X 3)$ sama dengan nol, maka nilai kepatuhan wajib pajak (Y) adalah sebesar negatif 13,531 satuan. Nilai koefisien determinasi menunjukkan bahwa nilai Adjusted $R$ Square sebesar 0,475 memiliki arti bahwa 47,5 persen kepatuhan wajib pajak dipengaruhi oleh program e-SAMSAT, SAMSAT keliling dan kepuasan wajib pajak. Sisanya 52,5 persen dipengaruhi oleh faktor atau variabel lain yang tidak masuk dalam model. Nilai signifikan $\mathrm{F}$ atau $p$-value sebesar 0,000 yang menunjukkan bahwa nilai tersebut lebih kecil dari 0,05 . Hal ini menunjukkan bahwa model mampu memprediksi fenomena penelitian.

Penelitian pada variabel program e-SAMSAT menunjukkan nilai 0,048< 0,05 sehingga variabel program e-SAMSAT berpengaruh positif pada kepatuhan wajib pajak. Koefisien regresi variabel program e-SAMSAT 0.071 yang bernilai positif. Berdasarkan hal tersebut maka hipotesis pertama dalam penelitian ini yaitu program e-SAMSAT berpengaruh positif pada kepatuhan wajib pajak kendaraan bermotor di Kantor Bersama SAMSAT Karangasem adalah diterima. Teori Technology Acceptance Model (TAM) relevan untuk menjelaskan bahwa 
dengan memanfaatkan teknologi yang ada penerapan e-SAMSAT dapat memudahkan wajib pajak dalam membayar pajak kendaraan bermotor.

Hasil penelitian ini sejalan dengan hasil penelitian Wardani \& Juliansya (2018) yang menyatakan bahwa program e-SAMSAT berpengaruh positif terhadap kepatuhan wajib pajak kendaraan bermotor karena dinilai efektif dan efisien dalam memberikan kemudahan kepada wajib pajak kendaraan bermotor dalam melakukan pembayaran pajak. Hertiarani (2016), yang menemukan bahwa pelayanan pajak kendaraan bermotor berjalan dengan efektif dan efisien dilihat dari pemberian pelayanan yang semakin cepat dan mudah dengan sistem real time online. Dewi \& Laksmi (2019) yang menyatakan bahwa penerapan e-SAMSAT dapat meningkatkan kepatuhan wajib pajak kendaraan bermotor. Hasil penelitian memberikan makna bahwa penerapan program e-SAMSAT yang semakin baik akan menjadikan kepatuhan wajib pajak semakin meningkat.

Penelitian pada variabel SAMSAT keliling menunjukkan nilai 0,000 $<0,05$ sehingga variabel SAMSAT keliling berpengaruh positif pada kepatuhan wajib pajak. Koefisien regresi variabel SAMSAT keliling 0.289 yang bernilai positif. Berdasarkan hal tersebut maka hipotesis kedua dalam penelitian ini yaitu SAMSAT keliling berpengaruh positif pada kepatuhan wajib pajak kendaraan bermotor di Kantor Bersama SAMSAT Karangasem adalah diterima. Theory of Planned Behaviour relevan untuk menjelaskan bahwa harapan seseorang untuk menyetujui atau memotivasi individu untuk mematuhinya (normative belief) adanya SAMSAT keliling akan memermudah wajib pajak dan dapat menghemat waktu dalam membayar kewajibannya dan akan meningkatkan tingkat kepatuhan wajib pajak.

Hasil penelitian ini sejalan dengan hasil penelitian Rohemah et al., (2016) menyatakan bahwa layanan SAMSAT keliling akses dan complain center berpengaruh terhadap kepatuhan wajib pajak. Mutia \& Hamta (2020) yang menyatakan bahwa SAMSAT keliling berpengaruh signifikan terhadap kepatuhan pajak kendaraan bermotor. Ardiyanti \& Supadmi (2020) yang menyatakan bahwa layanan SAMSAT keliling berpengaruh positif pada kepatuhan wajib pajak kendaraan bermotor. Hasil penelitian memberikan makna bahwa penerapan SAMSAT keliling yang baik dapat menjadikan kepatuhan wajib pajak semakin meningkat.

Penelitian pada variabel kepuasan wajib pajak menunjukkan nilai $0.000<0,05$ sehingga variabel kepuasan wajib pajak berpengaruh positif pada kepatuhan wajib pajak. Koefisien regresi variabel kepuasan wajib pajak 0,169 yang bernilai positif. Berdasarkan hal tersebut maka hipotesis ketiga dalam penelitian ini yaitu kepuasan wajib pajak berpengaruh positif pada kepatuhan wajib pajak kendaraan bermotor di Kantor Bersama SAMSAT Karangasem adalah diterima. Theory of Planned Behaviour relevan untuk menjelaskan bahwa dengan meningkatnya kepuasan wajib pajak akan memotivasi wajib pajak untuk patuh (normative belief).

Hasil penelitian ini sesuai dengan penelitian Dwipayana et al (2017) yang menyatakan bahwa kepuasan wajib pajak berpengaruh positif kepada kepatuhan wajib pajak. Hal ini juga didukung oleh penelitian yang dilakukan Awaluddin \& Tamburaka (2017) yang menyatakan bahwa kepuasan wajib pajak berpengaruh positif terhadap kepatuhan wajib pajak kendaraan bermotor. Hasil penelitian memberikan makna bahwa semakin tinggi tingkat kepuasan wajib pajak maka kepatuhan wajib pajak akan semakin meningkat. 


\section{SIMPULAN}

Penelitian ini bertujuan untuk mengetahui pengaruh program e-SAMSAT, SAMSAT keliling, dan kepuasan wajib pajak pada kepatuhan wajib pajak kendaraan bermotor. Berdasarkan hasil penelitian, Program e-SAMSAT berpengaruh positif pada kepatuhan wajib pajak kendaraan bermotor di Kantor Bersama SAMSAT Karangasem. Hal ini berarti bahwa penerapan program eSAMSAT yang semakin baik akan menjadikan kepatuhan wajib pajak semakin meningkat. SAMSAT keliling berpengaruh positif pada kepatuhan wajib pajak kendaraan bermotor di Kantor Bersama SAMSAT Karangasem. Hal ini berarti bahwa penerapan SAMSAT keliling yang semakin baik akan menjadikan kepatuhan wajib pajak semakin meningkat. Kepuasan wajib pajak berpengaruh positif pada kepatuhan wajib pajak kendaraan bermotor di Kantor Bersama SAMSAT Karangasem. Hal ini berarti bahwa semakin tinggi tingkat kepuasan wajib pajak maka kepatuhan wajib pajak akan semakin meningkat.

Berdasarkan simpulan, maka saran yang dapat diberikan yaitu bagi kantor SAMSAT khususnya di Kabupaten Karangasem, selain menerapkan program eSAMSAT dan SAMSAT keliling diharapkan dapat menerapkan pelayanan lainnya untuk menentukan solusi yang tepat dalam rangka meningkatkan kepatuhan wajib pajak berupa SAMSAT drive thru, SAMSAT corner, Layanan deliverry, dan lainnya. Berdasarkan hasil adjusted $R$ Square sebesar 47,5 persen kepatuhan wajib pajak dipengaruhi oleh program e-SAMSAT, SAMSAT keliling dan kepuasan wajib pajak dan sisanya 52,5 persen dipengaruhi oleh faktor lain, sehingga untuk peneliti selanjutnya dapat menambahkan variabel lain yang diduga dapat berpengaruh pada kepatuhan wajib pajak seperti sosialisasi perpajakan, pemahaman wajib pajak, pengetahuan wajib pajak, dan lainnya.

\section{REFERENSI}

Ardiani, L., Hidayat, K., \& Sulasmiyati, S. (2016). Implementasi Layanan Inovasi Samsat Keliling Dalam Upaya Meningkatkan Pelayanan Pembayaran Pajak Kendaraan Bermotor (Studi Pada Kantor Bersama SAMSAT Kabupaten Tulungagung). Jurnal Perpajakan (JEJAK).

Ardiyanti, N. P. M., \& Supadmi, N. L. (2020). Pengaruh Pengetahuan Perpajakan, Sosialisasi Perpajakan, dan Penerapan Layanan SAMSAT Keliling pada Kepatuhan Wajib Pajak. E-Jurnal Akuntansi. https://doi.org/10.24843/eja.2020.v30.i08.p02

Ariyanto, D. (2020). Influence of justice, culture and love of money towards ethical perception on tax evasion with gender as moderating variable. Journal of Money Laundering Control. https:/ / doi.org/10.1108/JMLC-06-2019-0047

Awaluddin, I. S. N. W. O. R. D. (2017). Pengaruh Kualitas Pelayanan Dan Kepuasan Wajib Pajak Terhadap Kepatuhan Membayar Pajak Kendaraan Bermotor. Jurnal Akuntansi Dan Keuangan Volume II/2/Oktober 2017.

Awaluddin, I., \& Tamburaka, S. (2017). The Effect of Service Quality and Taxpayer Satisfaction on Compliance Payment Tax Motor Vehicles at Office One Roof System in Kendari. The International Journal of Engineering and Science (IJES).

Chau, G., \& Leung, P. (2009). A critical review of Fischer tax compliance model : A research synthesis. Journal of Accounting and Taxation. 
Davis, J. S., Hecht, G., \& Perkins, J. D. (2003). Social behaviors, enforcement, and tax compliance dynamics. In Accounting Review. https://doi.org/10.2308/accr.2003.78.1.39

Dewi, I. G. A. M. R., \& P, K. W. L. (2019). Efektivitas E-Samsat, Pajak Progresif Dan Kualitas Pelayanan Terhadap Kepatuhan Wajib Pajak Kendaraan Bermotor. Jurnal Ilmiah Akuntansi Dan Bisnis. https:// doi.org/10.38043/jiab.v4i1.2151

Doran, M. (2009). Tax penalties and tax compliance. Harvard Journal on Legislation.

Ghouri, A. M., Khan, N. R., \& Abdul Kareem, O. B. (2016). Improving Employees Behavior through Extension in Theory of Planned Behavior: A Theoretical Perspective for SMEs. International Journal of Business and Management. https://doi.org/10.5539/ijbm.v11n11p196

Hartana, I. M. G., \& Merkusiwati, N. K. L. A. (2018). Sosialisasi Perpajakan Memoderasi Pengaruh Kesadaran Wajib Pajak dan Sanksi Perpajakan pada Kepatuhan Wajib Pajak. E-Jurnal Akuntansi. https://doi.org/10.24843/eja.2018.v25.i02.p26

Hertiarani, W. (2016). Implementasi Kebijakan E-Samsat Di Jawa Barat. Jurnal Ilmu Administrasi : Media Pengembangan Ilmu Dan Praktek Administrasi.

Mutia, N., \& Hamta, F. (2020). Pengaruh Penerapan Samsat Keliling, Samsat Corner Dan Drive Thru Terhadap Kepatuhan Wajib Pajak Kendaraan Bermotor Di Kota Batam. Measurement: Jurnal Akuntansi. https:// doi.org/10.33373/mja.v14i1.2439

Nyoman, N., Mahaputri, T., \& Noviari, N. (2016). Pengaruh Pemahaman Peraturan Perpajakan, Kesadaran Wajib Pajak Dan Akuntabilitas Pelayanan Publik Terhadap Kepatuhan Wajib Pajak. 17(32), 2321-2351.

Pau, M., \& Hammer, T. (2013). Sediment mapping and long-term monitoring of currents and sediment fluxes in pockmarks in the Oslofjord, Norway. Marine Geology. https://doi.org/10.1016/j.margeo.2013.09.012

Pertiwi, A. (2013). Pengaruh Sanksi Perpajakan Dan Kesadaran Wajib Pajak Terhadap Kepatuhan Perpajakan. Jurnal Dan Majalah Ilmiah UNIKOM.

Razak, ndash; (2013). Evaluating taxpayers attitude and its influence on tax compliance decisions in Tamale, Ghana. Journal of Accounting and Taxation. https://doi.org/10.5897/jat2013.0120

Rohemah, R., Kompyurini, N., \& Rahmawati, E. (2016). Analisis Pengaruh Implementasi Layanan Samsat Keliling Terhadap Kepatuhan Wajib Pajak Kendaraan Bermotor Roda Dua Di Kabupaten Pamekasan. Jurnal InFestasi.

Suseno, J., \& Sani, S. (2018). Pengaruh Kepuasan Wajib Pajak, Penegakan Sanksi Pajak Dan Keadilan Distributif Terhadap Kepatuhan Wajib Pajak Di Kota Pontianak. Jurnal Ekonomi Integra. https:// doi.org/10.51195/iga.v8i1.113

Torgler, B. (2005). Tax morale and direct democracy. European Journal of Political Economy. https://doi.org/10.1016/j.ejpoleco.2004.08.002

Wardani, D. K., \& Juliansya, F. (2018). Pengaruh Program E-Samsat Terhadap Kepatuhan Wajib Pajak Kendaraan Bermotor Dengan Kepuasan Kualitas Pelayanan Sebagai Variabel Intervening (Studi Kasus Samsat Daerah Istimewa Yogyakarta). Jurnal Akuntansi \& Manajemen Akmenika.

Wardani, D. K., \& Rumiyatun, R. (2017). Pengaruh Pengetahuan Wajib Pajak, Kesadaran Wajib Pajak, Sanksi Pajak Kendaraan Bermotor, Dan Sistem Samsat Drive Thru Terhadap Kepatuhan Wajib Pajak Kendaraan Bermotor. 
Jurnal Akuntansi. https://doi.org/10.24964/ja.v5i1.253

Winasari, A. (2020). Pengaruh Pengetahuan, Kesadaran, Sanksi, Dan Sistem ESAMSAT Terhadap Kepatuhan Wajib Pajak Kendaraan Bermotor Di Kabupaten Subang. (Studi Kasus Pada Kantor Samsat Subang). Prisma (Platform Riset Mahasiswa Akuntansi).

Winerungan, O. L. (2013). Sosialisasi Perpajakan, Pelayanan Fiskus Dan Sanksi Perpajakan Terhadap Kepatuhan Wpop Di Kpp Manado Dan Kpp Bitung. Jurnal Riset Ekonomi, Manajemen, Bisnis Dan Akuntansi. https://doi.org/10.35794/emba.v1i3.2301 